\title{
Management of Cushing's Disease After Failed Surgery - A Review
}

\author{
Nancy McLaughlin, Amin B. Kassam, Daniel M. Prevedello, Daniel F. Kelly
}

\begin{abstract}
Selective transsphenoidal adenomectomy is generally recommended for initial treatment of Cushing's disease (CD) because it achieves a high (70-85\%) rate of remission. However, if initial surgery is not successful, the approach to persistent or recurrent $\mathrm{CD}$ is more complex. Because residual or recurrent adenoma is typically found at the site of the original adenoma, repeat transsphenoidal surgery is recommended including selective adenomectomy, hemihypophysectomy or total hypophysectomy. If repeat pituitary surgery does not achieve remission, then possible adjuvant therapies include radiosurgery or stereotactic radiotherapy, bilateral adrenalectomy, and/or medical therapy. In all cases of persistent or recurrent $\mathrm{CD}$, successful treatment requires close collaboration of endocrinologists, radiation oncologists and neurosurgeons.
\end{abstract}

RÉSUMÉ: Revue du traitement de la maladie de Cushing suite à l'échec de la chirurgie. L'adénomectomie transsphénoïdale est généralement recommandée comme traitement initial de la maladie de Cushing (MC) parce que le taux de rémission obtenu est élevé, de l'ordre de $70 \%$ à $85 \%$. Cependant, si la chirurgie initiale est un échec, la conduite à tenir en cas de persistance ou de récidive de la MC est plus complexe. Étant donné que, de façon typique, l'adénome résiduel ou récidivant est situé à l'endroit où était situé l'adénome initial, une nouvelle chirurgie transsphénoïdale est recommandée, avec adénomectomie sélective, hémihypophysectomie ou hypophysectomie totale. Si une réintervention à l'hypophyse n'entraîne pas de rémission, des traitements adjuvants dont la radiochirurgie ou la radiothérapie stéréotaxique, la surrénalectomie bilatérale et/ou le traitement médical sont des options à considérer. Chez tous les cas de MC persistante ou récidivante, le succès du traitement dépend d'une collaboration étroite entre endocrinologues, radio-oncologues et neurochirurgiens.

Can. J. Neurol. Sci. 2011; 38: 12-21

Cushing's disease (CD) is the most common cause of Adrenocorticotropic Hormone (ACTH)-dependent Cushing's syndrome $^{l}$. It is defined as hypercortisolism caused by an ACTH-secreting pituitary adenoma, most often located within the anterior pituitary gland ${ }^{1}$. If left untreated, chronically elevated cortisol levels are associated with a fourfold increase in mortality ${ }^{2-3}$, largely related to abnormal glucose metabolism and cardiovascular complications including coronary heart disease, congestive heart disease and cerebrovascular events ${ }^{4-6}$. Transsphenoidal adenomectomy can normalize cortisol levels in approximately $70-85 \%$ of cases ${ }^{2,7-14}$. In these patients, remission is characterized by 4 to 18 months of sustained hypocortisolemia that requires steroid replacement before intrinsic cortisol function recovers ${ }^{15}$. After successful treatment of CD, age- and sex-adjusted survival rates approximate those of the general population.

Unfortunately, CD may persist in $7-31 \%^{12,16}$ and recur in 3$27 \%^{2,4,12,13,15,17-20}$ of patients who have undergone initial transsphenoidal surgery. When initial surgery fails, repeat surgery with selective adenomectomy, hemi-hypophysectomy or total hypophysectomy should be considered. If repeat surgery does not produce remission, adjuvant treatment options include radiation therapy, adrenolytic medical treatment, bilateral adrenalectomy, or a combination of adjuvant treatments. This review outlines the overall management of persistent or recurrent $C D$ after failed initial transphenoidal surgery, with special emphasis on the indications for repeat surgery and the specific techniques for re-operation (Figure 1).

Assessment following initial surgery and surveillance of patients in remission

\section{Early postoperative management}

Following initial transsphenoidal surgery, patients require close biochemical and clinical monitoring to determine whether remission has been achieved. Blood specimens for serum

From the Neuroscience Institute \& Brain Tumor Center, John Wayne Cancer Institute at Saint John's Health Center, Santa Monica, California, USA.

ReCeived May 4, 2010. Final Revisions Submitted July 13, 2010. Correspondence to: Daniel Kelly, Brain Tumor Center, John Wayne Cancer Institute at Saint John's Health Center, 2200 Santa Monica Blvd., Santa Monica, California, 90404, USA. 
cortisol and ACTH testing should be obtained twice daily ( 6 a.m. and 6 p.m.) on post-operative Days 1 and 2. Post-operative glucocorticoids should be withheld until hypocortisolemia (serum cortisol $\leq 5 \mu \mathrm{g} / \mathrm{dl}$ or $\leq 140 \mathrm{nmol} / \mathrm{liter}$ ) is documented, typically within $24-48$ hours of successful surgery ${ }^{10}$. Corticotroph function then is assessed at least every three months as glucocorticoid replacement therapy is slowly tapered. Sustained remission corresponds to at least six months of glucocorticoid replacement, followed by clinical and biochemical evidence of eucortisolemia (serum cortisol level and normal 24-hour urinary free cortisol). To ensure early detection of recurrence, patients should be followed up with 24-hour urinary free cortisol levels every six months for the first five years and at least annually thereafter ${ }^{1}$.

\section{Early prediction of long-term remission}

Several methods have been used to predict long-term remission from $\mathrm{CD}$. Provocative tests include the overnight lowdose dexamethasone suppression test and the corticotrophinreleasing hormone (CRH) stimulation test. Non-provocative tests include the measurement of morning serum cortisol and ACTH levels, and 24-hour urinary free cortisol concentrations within the early post-operative period. Recent studies indicate that both provocative and non-provocative tests are accurate for predicting remission? ${ }^{7}$. Most studies have measured early postoperative serum cortisol level ${ }^{12}$, but the timing of its measurement and the cut-off level for remission are variable. In a recently published series, a morning cortisol level of $5 \mu \mathrm{g} / \mathrm{dl}(\sim$ $140 \mathrm{nmol} /$ liter) or less on post-operative Day 1 or 2 was predictive of sustained remission in $97 \%$ of patients ${ }^{10}$. However, up to $4.5 \%$ of patients who achieve remission will not have a drop in cortisol levels during the first three days after surgery ${ }^{10,21-22}$. Also, undetectable cortisol values in the immediate post-operative period are not invariably associated with long-term remission ${ }^{23}$. In a large European multicenter study of CD, $4.3 \%$ of patients with undetectable serum cortisol levels in the immediate post-operative period developed relapse during follow-up ${ }^{19}$. Unmeasurable postoperative cortisol values predict a better outcome $e^{4,24-26}$ but does not eliminate the possibility of recurrence. Furthermore, Bochicchio and colleagues showed that $24.4 \%$ of patients with normal serum cortisol levels immediately after surgery eventually relapse ${ }^{19}$. In the early post-operative period a low-dose dexamethasone suppression test may help distinguish patients with durable remission from those who have residual tumor and will need early re-operation.

\section{Factors associated with a lower probability of remission}

Factors associated with a poorer surgical outcome include ACTH-producing macroadenomas that extend above the floor of the sella ${ }^{12}$, invade the cavernous sinus ${ }^{2,27,28}$, or infiltrate the dura (infiltration may be present without visible evidence of invasion during surgery ${ }^{2,28-30}$ ). In a recent series, initial remission rate was $86 \%$ for microadenomas, $83 \%$ for macroadenomas contained within the sella, $63 \%$ if macroadenomas extended above the floor of the sella, and $65 \%$ if tumor extended to the cavernous sinus $^{2}$. Not surprisingly, overall remission rates are lower and recurrence rates are higher $(12-45 \%)$ in patients with macroadenomas versus microadenomas ${ }^{27,29,31}$. Similarly, time to recurrence is shorter with macroadenomas versus microadenomas (mean 16 months vs 49 months) ) $^{27,29,31}$. In Dickerman and Oldfield's series, dural invasion was identified in $42(62 \%)$ of 68 patients with recurrent $\mathrm{CD}$, including all patients with macroadenomas and more than half of patients with microadenomas ${ }^{28}$. Most (93\%) of these invasive adenomas involved the cavernous sinus ${ }^{28}$.

In addition, clinicopathological studies have begun correlating the behavioral characteristics of pituitary tumors with histopathological and immunohistochemical features ${ }^{32}$. Specifically for $\mathrm{CD}$, it has been found that the absence of peritumoral Crooke's change may be a predictor of recurrence after successful surgical treatmen $t^{33}$. Normally, Crooke changes represent corticotroph cells' response to elevated glucocorticoid excess and is believed to functionally suppress these cells ${ }^{34}$. Therefore the absence of Crooke's changes indicates a lack of suppression, indicating that corticotroph cells may have some intrinsic abnormality predisposing to adenomatous islands and recurrence ${ }^{33}$. Interestingly, corticotroph adenomas composed mostly of Crooke's cells are aggressive when compared to typical corticotroph adenomas and have a higher recurrence rate $^{35}$. Overall, invasive pituitary adenomas tend to have a higher proliferative rate and immunopositivity for $\mathrm{p} 53^{32}$. Further assessment is required to characterize the histological features that may help predict long-term outcome and recurrence.

\section{Basis of persistent and recurrent Cushing disease}

The causes of failure after a first transsphenoidal surgery for $\mathrm{CD}$ may be due to the presence of residual tumor remaining hidden in the gland, in the cavernous sinus or less commonly in an ectopic parasellar region ${ }^{28}$. In most cases, residual tumor responsible for persistent or recurrent $\mathrm{CD}$ is found at or immediately contiguous to the site of the initial surgery ${ }^{28,36}$. Failure is often due to residual invasive tumor within the dura of the sella or in the cavernous sinus ${ }^{28,37}$. Dickerman found that unappreciated dural invasion within the cavernous sinus, even without evidence of invasion on MRI, is the basis of failure in many CD patients. ${ }^{28}$ Failed surgery may also result from the fact that the diagnosis of $\mathrm{CD}$ is incorrect. Other causes may include ectopic ACTH hypersecretion, corticotroph hyperplasia, pseudoCushing syndrome, and facticious Cushing syndrome $e^{9,13,27}$. Therefore, before repeat transsphenoidal surgery is performed on patients whose $\mathrm{CD}$ diagnosis is not confirmed by ACTH-staining adenoma in the first surgical specimen, the results of all preoperative endocrine and imaging evaluations must be carefully reviewed preferably in a multi-disciplinary fashion.

\section{Persistent Cushing's disease}

As stated above, $7-31 \%$ of $\mathrm{CD}$ patients do not achieve remission after a first transsphenoidal surgery ${ }^{12,16}$. Persistent $C D$ corresponds to a sustained elevation in post-operative cortisol levels and/or a need for therapy of CD within six months of initial surgery ${ }^{2}$. Its cause may be residual tumor hidden in the gland or less commonly in an ectopic site in the intrasellar or perisellar region ${ }^{28}$. Persistent $\mathrm{CD}$ may also be due to residual invasive tumor within the dura of the sella or the cavernous sinus $^{28,37}$. Rarely, nodular corticotroph hyperplasia of the pituitary gland may be responsible for a persistently elevated serum cortisol level ${ }^{9,13}$. Finally, postoperative hypercortisolism 
occasionally reflects a false diagnosis of CD; if the surgical specimen did not stain positive for $\mathrm{ACTH}$, all pre-operative endocrine and radiologic evaluations should be re-reviewed.

\section{Recurrent Cushing's Disease}

Recurrent $\mathrm{CD}$ is identified by clinical and biochemical characteristics of $\mathrm{CD}$ appearing more than six months after initial remission ${ }^{15}$. Large studies with prolonged follow-up have reported overall recurrence rates of $3-27 \%$; median postoperative time to recurrence is 2.3 to 7.2 years, or in rare cases as late as ten years $2,4,12,13,15-17,19,20,38$. Because most recurrences are due to regrowth of adenoma cells left in the peritumoral tissue during the first surgery ${ }^{28,36,39,40}$, repeat surgery should not be planned until the site of the initial tumor has been determined, often by reviewing the original operative note and the original pre-operative MRI.

\section{Imaging and inferior petrosal sinus sampling prior to repeat surgery}

A high quality pre-operative sellar MRI should be obtained before repeat surgery for persistent or recurrent $C D$. In Dickerman's series $53 \%$ of ACTH-secreting adenomas were detected on MRI performed prior to repeat surgery ${ }^{28}$. In this study, $52 \%$ of the tumors removed during repeat surgery measured less than $5 \mathrm{~mm}^{28}$. It must be noted however that preoperative MRI may not reveal a definitive adenoma; scar tissue and repair materials placed at the original surgery may also be misleading ${ }^{40}$. Dynamic MRIs which acquire images within seconds after the injection have shown improved sensitivity but decreased specificity compared to conventional static MRIs ${ }^{4 !}$. Recent studies have found that 3 Tesla MRI of the pituitary gland are also more sensitive to pituitary adenomas than 1.5 Tesla images of the sella region ${ }^{42}$. It has been proposed that dynamic post-gadolinium 3 Tesla MRIs should be included in the investigation of patients with CD when 1.5 Tesla imaging is negative or equivocal ${ }^{42,43}$. However the utility of 3 Tesla MRI in patients with recurrent $C D$ is unproven.

For patients with a negative or ambiguous MRI, inferior petrosal sinus sampling (IPSS) may help establish the etiology of ACTH hypersecretion and can help localize the side of the microadenoma ${ }^{16,40}$. If not performed prior to the initial surgery and there is some doubt as to whether the patient actually has CD, IPSS using CRH stimulation may be useful to confirm a pituitary origin of ACTH secretion and potentially localize the side of the adenoma ${ }^{1,15,29,44,45}$. However, in patients with proven CD who have a recurrence, there is relatively little utility to IPSS given that the test is only $50 \%$ accurate in predicting tumor laterality $^{40}$, and this invasive procedure carries some risk of potential complications.

\section{Timing of repeat intervention}

If hypercortisolism persists more than three days following transsphenoidal surgery, a repeat operation should be considered in the immediate post-operative period, especially if the preoperative imaging was positive, if a tumor was visualized during first surgery and if the pathology showed ACTH-positive staining tumor ${ }^{8}$.
Repeat surgery within the first post-operative week has several advantages. First, it allows re-exploration of the sella with minimal additional trauma, because it is undertaken before the formation of scar tissue and modification of surgical anatomy ${ }^{45,46}$. Second, the surgeon often is able to recall particular anatomical details from the earlier operation, which may be essential to the re-exploration ${ }^{46}$. Third, immediate repeat surgery avoids the deleterious effects of continued hypercortisolism, and prevents the potential problems associated with the alternative adjuvant treatments. Finally, as compared with delayed repeat surgery, early repeat surgery for persistent $\mathrm{CD}$ has a relatively low morbidity ${ }^{46}$.

In patients with recurrent $C D$, repeat surgery should be performed as soon as the diagnosis of recurrence is clearly established.

\section{Surgical strategy for the management of failed trans- sphenoidal procedure}

Once the diagnosis of persistent/recurrent $\mathrm{CD}$ is established, selective removal of the persistent/recurrent adenoma by transsphenoidal surgery is the preferred first treatment option, as it is for newly diagnosed CD. As described below, some patients may require more aggressive removal of the gland by hemihypophysectomy or even total hypophysectomy $11,14,40,47$.

Because of significant scar tissue and altered normal anatomy, repeat surgery for recurrent pituitary adenomas is in general more challenging than an initial operation or an immediate re-operation for persistent disease. Adhesions of soft tissues may complicate access to the sphenoid sinus and sella. If bony closure of the operated sella is encountered, careful reopening of the sellar face is required. The extent of bony removal can be adapted to the presumed location of the persistent/recurrent adenoma but in general a wide exposure is essential. A wide and tall sphenoidotomy will allow access to the entire sella; bone removal over the sellar face should extend laterally beyond the medial portions of the cavernous sinus, superiorly to the planum - tuberculum junction, and inferiorly to the sellar floor. This exposure over the cavernous sinus is particularly important if the original tumor was in the lateral aspect of the gland or sella. Altered anatomic conditions in revision surgery require particular precautions to identify key neurovascular structures, especially the cavernous carotid arteries. Surgical navigation and the Doppler probe are highly recommended for localizing the portion of the internal carotid artery within the cavernous sinus and for confirming regional anatomy ${ }^{48,49}$.

For persistent and recurrent $C D$, once the sella is reached, the first step of repeat surgery should be a thorough re-exploration of the original resection site. Several studies indicate that most cases are due to adenoma cells that persist/recur locally and that a selective adenomectomy is typically possible $28,36,39,40$. The Table 1 summarizes the reported series of persistent/recurrent CD treated by repeat surgery. In a series of eight patients undergoing repeat surgery for recurrent $C D$, Nakane et al reported that all recurrent adenomas were at the site of the original tumor ${ }^{36}$. Patil et al reported 36 cases of recurrent CD: $67 \%$ underwent selective adenomectomy and only $14 \%$ required a total hypo-physectomy ${ }^{47}$. In a study by Hofmann et al, 13 of the 16 patients undergoing repeat surgery for recurrent $\mathrm{CD}$ had 
recurrent adenoma in the original tumor bed ${ }^{40}$. In Dickerman and Oldfield's series of 68 patients with recurrent CD, all 43 patients in whom tumor was found at the first surgery had recurrent tumor at the same site or an immediately contiguous site ${ }^{28}$.

Given these observations, it appears the origin of recurrent tumor is typically in the original tumor bed within the pituitary gland or in the adjacent cavernous sinus, presumably resulting from growth of microscopic tumor rests left behind during the original surgery ${ }^{40}$. If the original tumor site was in the lateral sella, even in instances with an initial negative MRI, wide exploration of the lateral sellar area and clear visualization of the medial cavernous sinus wall are essential. Once the tumor is encountered, a selective extracapsular dissection should be attempted but may not be feasible because of scarring related to the prior surgery ${ }^{11,50}$. Adhesions between the tumor wall and the cavernous sinus are not uncommon in patients with recurrent/persistent $C D$. If the tumor-gland interface is illdefined, it is usually prudent and safe to include a margin of normal-appearing gland, working medially from the tumor: This thin rim of normal gland increases the likelihood of remission and carries only a low risk of new hypopituitarism ${ }^{51}$.

Regarding possible cavernous sinus invasion by adenoma, adhesions may be present between the tumor wall and the cavernous sinus. Given the high frequency of dural invasion in recurrent tumors, adequate exposure of the medial cavernous sinus and sellar floor dura is essential in repeat surgeries for $\mathrm{CD}^{28}$. Enhanced anatomical knowledge of the parasellar area, surgical navigation systems and high-definition endoscopy have improved the safe and effective surgical access to this region $^{52-54}$. After sellar tumor removal, zero-degree and angled endoscopes should be used to visualize the lateral sella and medial cavernous sinus. Although the medial cavernous sinus can often be visualized with the purely microscopic view, the endoscope's more panoramic view may allow more complete removal of cavernous sinus tumor. If tumor extends into the cavernous sinus through a defect of the medial cavernous sinus wall, this dura can be incised under direct endoscopic or microscopic visualization. Tumor within the medial cavernous sinus can be removed using gentle suction and ring currettes. Abnormal-appearing dura in the medial wall of the cavernous simus should also be removed and dural edges should be lightly cauterized. However, great care must be taken to avoid injuring the cavernous carotid artery. In experienced hands, surgical management of pituitary adenomas invading the cavernous sinus does not result in permanent cranial nerve palsy or internal carotid artery injury ${ }^{28,55}$.

If no tumor is visualized on pre-operative MRI, sequential vertical incisions in the gland are performed ${ }^{50}$. A bilateral periglandular inspection with visualization of the medial wall of both cavernous sinuses and of the diaphragm is also performed in order to identify tumoral tissue. Hemihypophysectomy or total hypophysectomy are performed more frequently in repeat surgery than at initial surgery ${ }^{7}$. However, the role of total hypophysectomy for patients with new or recurrent $\mathrm{CD}$ remains controversial, in part because the remission rate following total hypophysectomy ranges from $0-100 \% 47,56$. Also, total hypophysectomy increases the risk of post-operative hypopituitarism ${ }^{8}$. If complete removal of invasive tumor is not possible or if no definitive tumor is identified, the residual gland can be mobilized and separated from the invasive site by an intervening fat graft; this graft protects the gland during postoperative radiotherapy and thereby reduces the risk of hypopituitarism.

If no tumor is found in the anterior lobe, the interface between anterior and posterior lobes should be carefully explored. A small subset of patients may have residual tumor in this region of the sella or within the posterior lobe itself $f^{57}$. In order to gain access to the posterior lobe, a $2-\mathrm{mm}$ vertical crevice is created in the anterior gland, exposing the gelatinous contents of the intermediate lobe and afterwards the anterior surface of the posterior lobe ${ }^{57}$. According to Weil and colleagues, ACTHsecreting adenomas within the posterior lobe generally have a pale gray-blue or gray-brown color visible on inspection of the neurohypophysis ${ }^{57}$. However, if the entire posterior lobe must be removed to treat an invasive adenoma, insertion of the infundibulum into the hypophysis should be sharply cut, avoiding traction on the stalk and minimizing the risks of permanent diabetes insipidus (Edward Laws, personal communication, February 2010).

\section{Potential complications of repeat surgery}

The higher rate of post-operative hypopituitarism after repeat surgery is related in part to the extent of pituitary tissue removed ${ }^{14}$. Overall, the risk of new hormonal deficiencies after a repeat transsphenoidal operation varies between $2-50 \%$ and is usually around $20 \% 8,14,46,47,58$. Importantly, the risk of hypopituitarism after repeat surgery appears to be lower than reported rates of hypopituitarism occurring several years after radiotherapy ${ }^{8}$. Post-operative CSF leaks have been reported more frequently after repeat transsphenoidal surgery than firsttime surgery ${ }^{45,46,59}$. Chee et al found that rates were $46 \%$ after repeat transsphenoidal surgery versus $13 \%$ after initial transsphenoidal surgery ${ }^{60}$. However, in experienced hands the risk of CSF leak following repeat endonasal transsphenoidal surgery may be minimal ${ }^{47}$. In our experience, only one, patient with repeat surgery for failed CD developed a CSF leak postoperatively ${ }^{10}$.

\section{Remission after repeat surgery}

Repeat surgery using a microsurgical, endoscopic-assisted or purely endoscopic approach can produce remission in most patients with persistent/recurrent $C D$. The remission rate following repeat surgery using specifically the conventional microscope technique varies from 37-87.5\% (Table 1) (simple [unweighted] average $66 \%$ ). However, relapse after repeated surgery ranges from 0 to $35 \%$ at a mean follow-up of 31 months ${ }^{61}$. More recently, Wagenmakers et al has reported the first series of data on repeated transsphenoidal surgery using a purely endoscopic technique for patients with persistent or recurrent $\mathrm{CD}^{14}$. Remission was obtained in $71 \%$ of patients $(50 \%$ of persistent $\mathrm{CD}$ and $87.5 \%$ of recurrent $\mathrm{CD}^{14}$. None of these cases relapsed during a mean follow-up of 34 months ${ }^{14}$. These results suggest that purely endoscopic surgery is at least as good as the microscopic technique for repeat surgery. Additional prospective collection of data using the purely endoscopic technique in experienced centers is necessary to confirm these preliminary favorable results. 
Table: Studies of repeat transsphenoidal surgery for persistent or recurrent Cushing's disease

\begin{tabular}{|c|c|c|c|c|c|}
\hline & $\mathbf{N}$ & $\begin{array}{l}\text { Criteria for } \\
\text { Remission }\end{array}$ & $\begin{array}{l}\text { Remission } \\
\text { Rate }\end{array}$ & $\begin{array}{l}\text { Relapse } \\
\text { Rate }\end{array}$ & $\begin{array}{l}\text { Mean } \\
\text { Follow-up }\end{array}$ \\
\hline $\begin{array}{l}\text { Nakane et al } \\
(1987)^{36}\end{array}$ & $8 \mathrm{R}$ & $\mathrm{N} / \mathrm{R}$ & $87.5 \%$ & N/R & $\mathrm{N} / \mathrm{R}$ \\
\hline $\begin{array}{l}\text { Friedman et al } \\
(1989)^{58}\end{array}$ & 31P\&R & $\begin{array}{l}\text { Morning } \mathrm{C} \leq 6 \mu \mathrm{g} / \mathrm{dl} \\
\mathrm{UFC}<90 \mu \mathrm{g} / \text { day }\end{array}$ & $71 \%$ & $13.6 \%$ & 11 months \\
\hline Ram et al $(1994)^{46}$ & $17 \mathrm{P}$ & $\begin{array}{l}\text { Morning } \mathrm{C} \leq 5 \mu \mathrm{g} / \mathrm{dl} \\
\mathrm{UFC}<90 \mu \mathrm{g} / \text { day }\end{array}$ & $71 \%$ & $25 \%$ & $\begin{array}{l}34 \text { months } \\
\text { (range, 4-84) }\end{array}$ \\
\hline $\begin{array}{l}\text { Knappe el al } \\
(1996)^{39}\end{array}$ & $\begin{array}{l}16 \mathrm{P} \\
24 \mathrm{R}\end{array}$ & $\mathrm{N} / \mathrm{R}$ & $\begin{array}{l}P: 70.8 \% \\
R: 56.3 \%\end{array}$ & $\begin{array}{l}\mathrm{P}: 24 \% \\
\mathrm{R}: 22 \%\end{array}$ & $\mathrm{~N} / \mathrm{R}$ \\
\hline $\begin{array}{l}\text { Shimon et al } \\
(2002)^{13}\end{array}$ & $13 \mathrm{P} \& \mathrm{R}$ & $\begin{array}{l}\text { Clinical resolution of } \\
\text { hypercortisolism; } \\
\text { Normalization of UFC; Suppression } \\
\text { of C levels by } \\
48 \text {-h Jow-dose Dexa }\end{array}$ & $62 \%$ & $\mathrm{~N} / \mathrm{R}$ & $N / R$ \\
\hline $\begin{array}{l}\text { Locatelli et al } \\
(2005)^{45}\end{array}$ & $12 \mathrm{P}$ & $\begin{array}{l}\text { Clinical symptoms of } \\
\text { hypocortisolism; } \\
\text { Morning } C \leq 2 \mu \mathrm{g} / \mathrm{dl}\end{array}$ & $67 \%$ & 0 & $\begin{array}{l}27 \text { months } \\
\text { (range, 3-84) }\end{array}$ \\
\hline $\begin{array}{l}\text { Benveniste el al } \\
(2005)^{6}\end{array}$ & $12 \mathrm{P} / 30 \mathrm{R}$ & $\mathrm{N} / \mathrm{R}$ & $57 \%$ & $35 \%$ & 31 months \\
\hline $\begin{array}{l}\text { Hofinann et al } \\
(2006)^{40}\end{array}$ & $16 \mathrm{R}$ & $\begin{array}{l}\text { Morning C } 10-21 \mu \mathrm{g} / \mathrm{dl} ; \\
\mathrm{C}<2 \mu \mathrm{g} / \mathrm{dl} \text { after } 2 \mathrm{mg} \text { Dexa }\end{array}$ & $37 \%$ & 0 & $N / R$ \\
\hline $\begin{array}{l}\text { Hofmann et al } \\
(2008)^{11}\end{array}$ & $35 \mathrm{P} \& \mathrm{R}$ & $\begin{array}{l}\text { Clinical remission; } \mathrm{C}<2 \mu \mathrm{g} / \mathrm{dl} \text { after } 2 \\
\text { mg Dexa }\end{array}$ & $37.1 \%$ & $\mathrm{~N} / \mathrm{R}$ & $\mathrm{N} / \mathrm{R}$ \\
\hline $\begin{array}{l}\text { Aghi et al } \\
(2008)^{18}\end{array}$ & $\begin{array}{l}10 \mathrm{P} \\
13 \mathrm{R}\end{array}$ & Morning $\mathrm{C} \leq 5 \mu \mathrm{g} / \mathrm{dl} ; \mathrm{UFC}<20 \mu \mathrm{g} / \mathrm{day}$ & $\begin{array}{l}\mathrm{P}: 70 \% \\
\mathrm{R}: 77 \%\end{array}$ & N/R & $\mathrm{N} / \mathrm{R}$ \\
\hline $\begin{array}{l}\text { Patil et al } \\
(2008)^{47}\end{array}$ & $36 \mathrm{R}$ & Elevated $24-\mathrm{hr}$ UFC & $61 \%$ & $9.1 \%$ & 36 months \\
\hline $\begin{array}{l}\text { Wagenmakers et al } \\
(2009)^{14}\end{array}$ & $\begin{array}{l}6 \mathrm{P} \\
8 \mathrm{R}\end{array}$ & $\begin{array}{l}\text { Clinical remission; } \\
\mathrm{C} \leq 50 \mathrm{nmol} / \mathrm{l} \text { after glucocorticoid } \\
\text { withdrawal for } 24-48 \mathrm{~h} ; \mathrm{C} \leq 50 \mathrm{nmol} / \mathrm{l} \\
\text { after overnight } 1 \mathrm{mg} \text { Dexa within } \\
\text { first } 3 \text { months }\end{array}$ & $71 \%$ & 0 & 34 months \\
\hline
\end{tabular}

Dexa, Dexamethasone. N, number of patients undergoing repeat surgery. N/R, not reported. P, persistent Cushing's disease. R, recurrent Cushing's disease. C, serum cortisol. UFC, urinary free cortisol

\section{Adjuvant radiotherapy for persistent or recurrent Cushing's disease}

If repeat transsphenoidal surgery does not produce biochemical remission of persistent/recurrent $\mathrm{CD}$, adjuvant treatment should begin immediately 1,16,62. Adjuvant treatment options include radiation therapy, medical therapy, bilateral adrenalectomy, or a combination of multiple treatments. In the 36 patients described by Patil et al, 61\% achieved remission of recurrent $\mathrm{CD}$ with surgery alone, and $22 \%$ achieved remission after surgery plus adjuvant therapy, for a total success rate of
$83 \%{ }^{47}$. Adjuvant treatments used in this study were radiosurgery, adrenalectomy and/or Ketoconazole therapy.

Although radiation was widely used for first-line treatment of CD from the 1940 s to the early 1980 s, it is now more likely to be a secondary treatment after failed transsphenoidal surgery $7,8.15,27,62$. Conventional fractionated radiation therapy has historically been the primary radiation regimen used to treat CD. Reported remission rates vary from $56-83 \%$, with an average time to remission of two years ${ }^{14,63}$. The incidence of hypopituitarism after fractionated radiation therapy ranges from 50 to $100 \%$ several years after treatment ${ }^{64,65}$. Other less common 
complications related to fractionated radiotherapy include radiation necrosis, cerebral vasculopathy, damage to surrounding sellar and parasellar structures, and development of radiation neoplasm ${ }^{28,66-69}$.

Few studies have specifically assessed the efficacy of fractionated stereotactic radiotherapy (SRT) for $\mathrm{CD}^{70,71}$. In a study reported by Colin at al, SRT produced remission in 9 $(75 \%)$ of 12 patients at a mean of 29 months ${ }^{70}$. In this series, the toxicity was significantly lower for ACTH-secreting pituitary adenomas, with no radio-induced pituitary deficiency and no neurological or optic injury ${ }^{70}$. Theoretically, SRT focused to the target volume may be more suitable than conventional external radiotherapy. However, series with larger populations and longer follow-ups are required to evaluate radiation-induced delayed complications and determine the incidence of biochemical recurrence.

Single-treatment stereotactic radiosurgery (SRS) using photon beams has replaced conventional fractionated radiation therapy as the primary radiation modality for persistent or recurrent $\mathrm{CD}^{8,72}$, because one high dose has a larger radiobiological effect than multiple lower doses when the target is a slow-growing lesion. In the three largest series of patients who underwent adjuvant radiosurgery using the gamma knife (single fraction therapy), cortisol production normalized in $63 \%$ at an average of 12.1 months $^{73}$, in $54 \%$ at an average of 13 months $\mathrm{s}^{74}$, and in $43 \%$ at an average of 22 months $^{75}$. Despite initial enthusiasm for SRS with gamma knife, the relapse rate is high (up to $20 \%$ ) $^{73-76}$. Also, the incidence of new-onset hypopituitarism requiring replacement therapy after SRS is 16 $55 \%$, with a median time to onset of 50-60 months ${ }^{74-77}$. However, SRS seems to lead to faster normalization of hormone levels with lower risk of hypopituitarism and visual deterioration in comparison to fractionated radiotherapy ${ }^{73,74}$. Since recurrences of $\mathrm{CD}$ and hormonal deficiencies may arise during long-term follow-up, biochemical surveillance is indicated.

Recently, two groups have reported their results with protonbeam radiosurgery 18,78 . Proton-beam radiosurgery offers improved dose distributions as compared with photon beams ${ }^{18,79}$. These studies obtained remission rates of $52 \%$ and $58 \%$, similar to those obtained with gamma knife SRS ${ }^{18,78}$. The toxic effects to the cranial nerve and the disease recurrence rates are slightly lower than those with the gamma knife ${ }^{18}$. However, the incidence of hypopituitarism is $42 \%-52 \%$ in recent studies ${ }^{18,78}$. Larger series with longer follow-up are required to assess the advantages of proton beam radiosurgery over gamma knife SRS, as well as the occurrence of late radiation-related sequelae.

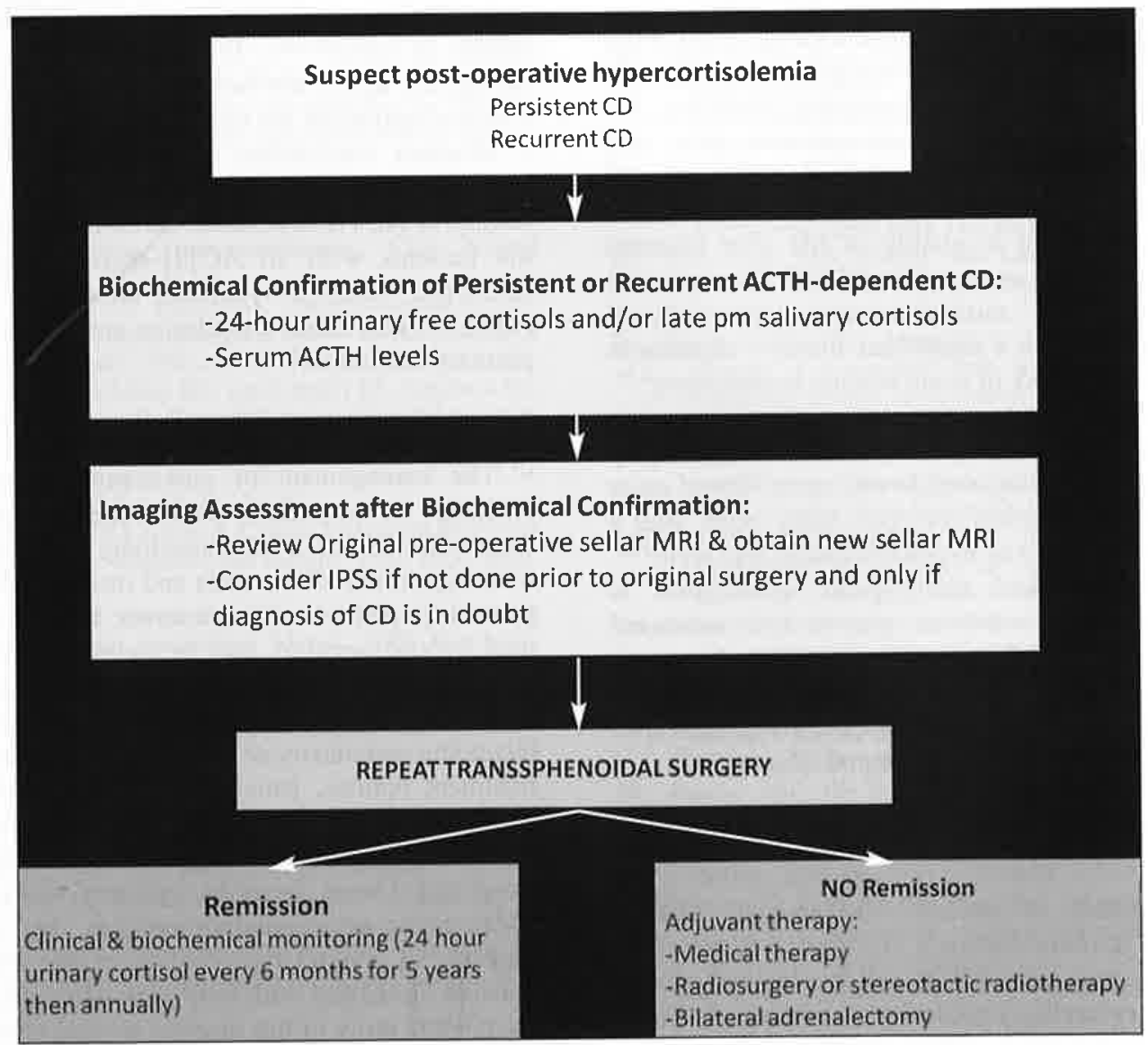

Figure 1: Schematic summary of the management of Cushing's disease after failed surgery 


\section{Adjuvant medical treatment}

Medical treatment is used to improve a patient's clinical condition before transsphenoidal surgery or before radiation treatment produces its effect. It may also be used when curative resection was prevented by the tumor's size or extent, and for patients who refuse surgery. Overall, medical treatment may be useful in up to one-third of $\mathrm{CD}$ patients ${ }^{80}$. Medical treatment for $\mathrm{CD}$ includes drugs inhibiting steroidogenesis such as Ketoconazole, cortisol-receptor antagonists such as mifepristone, drugs modulating ACTH release such as somatostatin analogues (Octreotide), and dopamine agonists (Bromocriptine) $)^{8.16 .81}$. Medical treatment requires lifelong administration and cortisol monitoring to keep cortisol levels in normal ranges. If it is used to bridge the interval before radiation treatment takes effect, it may be discontinued once remission has been documented.

\section{Bilateral adrenalectomy}

Bilateral adrenalectomy immediately reverses hypercortisolism in $88-100 \%$ of cases $^{7}$ but should only be considered when pituitary-directed treatments of persistent/recurrent $C D$ have failed or are contraindicated. Typically, candidates for bilateral adrenalectomy have already undergone multiple surgeries and/or radiosurgeries, or may be unable to obtain medical control of their hypercortisolism without adverse effects.

Open adrenalectomy has been associated with 23\% perioperative morbidity and $4 \%$ operative mortality ${ }^{82}$. More recently, laparoscopic adrenalectomy has become accepted as the standard approach for resection of most benign adrenal lesions ${ }^{83}$. Recent series have reported $10 \%$ peri-operative morbidity, $1 \%$ peri-operative mortality, decreased post-operative pain, and shorter hospital stay ${ }^{83,84}$. Although there are persistent quality of life deficits after biochemical remission of $\mathrm{CD}$, numerous studies have found an improvement in quality of life after bilateral adrenalectomy for persistent or recurrent $\mathrm{CD}^{83,85}$. However, the requirement for lifelong mineralo- and glucocorticoid replacement therapy requires a significant lifestyle adjustment and does not eliminate the risk of acute adrenal insufficiency ${ }^{1.15}$. Moreover, residual adrenal rests and accessory glands located in various sites can regrow under the chronic stimulation of highly elevated ACTH levels. This may explain why up to $10 \%$ of cases may resume endogenous cortisol secretion many years after a bilateral adrenalectomy, and why hypercortisolism may recur ${ }^{1,62}$.

Clinical, biochemical and radiological surveillance is necessary to monitor for adenoma growth and increased ACTH plasma levels following bilateral adrenalectomy ${ }^{1}$. Adrenocorticotropic Hormone plasma levels should be measured and a pituitary MRI should be obtained three to six months after bilateral adrenalectomy and at regular intervals thereafter ${ }^{62}$.

\section{Onset and management of Nelson's syndrome after bilateral adrenalectomy}

Approximately $8-46 \%$ of patients who undergo bilateral adrenalectomy will develop Nelson's syndrome ${ }^{86.90}$, which is characterized by elevated serum $\mathrm{ACTH}$, skin hyperpigmentation, and progressively enlarging corticotropic adenomas. These adenomas are often invasive ${ }^{7,91}$. Most cases occur five to ten years after surgery, but this interval may be as short as six months or as long as 24 years ${ }^{88-89.92}$.

There is no proven medical treatment for corticotroph tumor progression after bilateral adrenalectomy ${ }^{62}$. Early repeat transsphenoidal surgery and/or radiotherapy should be conducted as soon as significant tumor growth occurs ${ }^{93}$. However, neurosurgical management of Nelson syndrome is challenging due to the aggressive and often invasive nature of these ACTH-producing adenomas. In five patient series published from 1982 to 2002, surgery was effective in improving or restoring vision and reducing the degree of hyperpigmentation ${ }^{93-97}$. However, the ACTH levels normalized in fewer than $50 \%$ of patients and additional radiation therapy was required in $20-30 \%$ patients to help control tumor growth ${ }^{93.97}$.

Fractionated external beam radiotherapy or stereotactic radiosurgery has been used in patients with Nelson syndrome after bilateral adrenalectomy to complement or replace repeat transsphenoidal surgery ${ }^{62,72,77,78,98}$. Although remission rate was only $0-36 \%$, tumor growth was controlled in $82-100 \%$ of cases $^{77.98}$. One study investigated prophylactic radiation after bilateral adrenalectomy. Although prior radiation therapy reduced the risk and delayed the onset of Nelson's syndrome ${ }^{99}$ further studies are required before preventive radiotherapy can be recommended ${ }^{15,62}$.

Currently, there is no proven efficacious medical treatment for corticotroph tumor progression after bilateral adrenalectomy ${ }^{62}$. Dopamine agonists such, as cabergoline, have been used with variable success ${ }^{100}$. Multireceptor ligand somatostatin analogue, such as pasireotide, has shown favorable results in vitro ${ }^{101,102}$. Temozolomide, an alkylating chemotherapeutic agent, has been reported in two case reports as an effective option for the treatment of Nelson's syndrome ${ }^{103}$.

Pituitary carcinomas occur in $0.1-0.2 \%$ of all pituitary adenomas $^{104}$. Of all the reported cases, $42 \%$ occurred in the setting of ACTH-dependent adenomas. Approximately half of the patients with an ACTH-secreting pituitary carcinoma developed Nelson's syndrome throughout their follow-up ${ }^{105}$. Patients with Nelson's syndrome are also at risk of developing pituitary carcinoma ${ }^{7.91}$.

\section{CONClusion}

The management of persistent/recurrent $C D$ remains a challenge for the pituitary neurosurgeon. Repeat transsphenoidal surgery for selective adenomectomy is the treatment of choice, with exploration of the sella and medial walls of the cavernous sinuses for possible invasive tumor. In some instances, hemi- or total hypophysectomy may be indicated. When repeat surgery fails, other treatment options include SRS or SRT, medical treatment with ketoconazole and/or bilateral adrenalectomy. Given the complexity of this disorder and the wide spectrum of treatment options, patients with failed initial transsphenoidal surgery are best cared for by a multidisciplinary team comprising neurosurgeons specializing in pituitary lesions, Ear, Nose and Throat surgeons, pituitary endocrinologists, radiooncologists, neuro-ophthalmologists, and general surgeons. Because of the relative challenges of altered anatomy and scarring associated with both persistent and recurrent $\mathrm{CD}$, and the relative rarity of this disease, we and others recommend that patients be treated at specialized pituitary centers ${ }^{8,14}$. 


\section{REFERENCES}

1. Bertagna X, Guignat L, Groussin L, Bertherat J. Cushing's disease. Best Pract Res Clin Endocrinol Metab. 2009 Oct;23(5):607-23.

2. Hammer GD, Tyrrell JB, Lamborn KR, et al. Transsphenoidal microsurgery for Cushing's disease: initial outcome and longterm results. J Clin Endocrinol Metab. 2004 Dec;89(12): 6348-57.

3. Lindholm $\mathbf{J}$, Juul $\mathrm{S}$, Jorgensen $\mathrm{JO}$, et al. Incidence and late prognosis of cushing's syndrome: a population-based study. J Clin Endocrinol Metab. 2001 Jan;86(1):117-23.

4. Atkinson AB, Kennedy A, Wiggam MI, McCance DR, Sheridan B. Long-term remission rates after pituitary surgery for Cushing's disease: the need for long-term surveillance. Clin Endocrinol (Oxf). 2005 Nov;63(5):549-59.

5. Mancini T, Kola B, Mantero F, Boscaro M, Arnaldi G. High cardiovascular risk in patients with Cushing's syndrome according to 1999 WHO/ISH guidelines. Clin Endocrinol (Oxf). 2004 Dec;61(6):768-77.

6. Ross EJ, Linch DC. The clinical response to treatment in adult Cushing's syndrome following remission of hypercortisolacmia. Postgrad Med J. 1985 Mar;61(713):205-11.

7. Kelly DF. Transsphenoidal surgery for Cushing's disease: a review of success rates, remission predictors, management of failed surgery, and Nelson's Syndrome. Neurosurg Focus. 2007;23 (3): $\mathrm{E} 5$.

8. Liu JK, Fleseriu M, Delashaw JB, Jr., Ciric IS, Couldwell WT. Treatment options for Cushing disease after unsuccessful transsphenoidal surgery. Neurosurg Focus. 2007;23(3):E8.

9. Dehdashti AR, Gentili F. Current state of the art in the diagnosis and surgical treatment of Cushing disease: early experience with a purely endoscopic endonasal technique. Neurosurg Focus. 2007; 23(3):E9.

10. Esposito F, Dusick JR, Cohan P, et al. Clinical review: early morning cortisol levels as a predictor of remission after transsphenoidal surgery for Cushing's disease. J Clin Endocrinol Metab. 2006 Jan;91(1):7-13.

11. Hofmann BM, Hlavac M, Martinez R, Buchfelder M, Muller OA, Fahlbusch R. Long-term results after microsurgery for Cushing disease: experience with 426 primary operations over 35 years. J Neurosurg. 2008 Jan;108(1):9-18.

12. Fomekong E, Maiter D, Grandin C, Raftopoulos C. Outcome of transsphenoidal surgery for Cushing's disease: a high remission rate in ACTH-secreting macroadenomas. Clin Neurol Neurosurg. 2009 Jun;111(5):442-9.

13. Shimon I, Ram Z, Cohen ZR, Hadani M. Transsphenoidal surgery for Cushing's disease: endocrinological follow-up monitoring of 82 patients. Neurosurgery. 2002 Jul;51(1):57-61; discussion -2.

14. Wagenmakers MA, Netea-Maier RT, van Lindert EJ, Timmers HJ, Grotenhuis JA, Hermus AR. Repeated transsphenoidal pituitary surgery (TS) via the endoscopic technique: a good therapeutic option for recurrent or persistent Cushing's disease (CD). Clin Endocrinol (Oxf). 2009 Feb;70(2):274-80.

15. Beauregard C, Dickstein G, Lacroix A. Classic and recent etiologies of Cushing's syndrome: diagnosis and therapy. Treat Endocrinol. 2002;1(2):79-94.

16. Aghi MK. Management of recurrent and refractory Cushing disease. Nat Clin Pract Endocrinol Metab. 2008 Oct;4(10): 560-8.

17. Barbetta L, Dall'Asta C, Tomei G, Locatelli M, Giovanelli M, Ambrosi B. Assessment of cure and recurrence after pituitary surgery for Cushing's disease. Acta Neurochir (Wien). 2001;143 (5):477-81; discussion 81-2.

18. Aghi MK, Petit J, Chapman P, et al. Management of recurrent and refractory Cushing's disease with reoperation and/or proton beam radiosurgery. Clin Neurosurg. 2008;55:141-4.

19. Bochicchio D. Losa M, Buchfelder M. Factors influencing the immediate and late outcome of Cushing's disease treated by transsphenoidal surgery: a retrospective study by the European Cushing's Disease Survey Group. J Clin Endocrinol Metab. 1995 Nov;80(11):3114-20.
20. Hofmann BM, Fahlbusch R. Treatment of Cushing's disease: a retrospective clinical study of the latest 100 cases. Front Horm Res. 2006;34:158-84.

21. Rollin GA, Ferreira NP, Junges M, Gross JL, Czepielewski MA Dynamics of serum cortisol levels after transsphenoidal surgery in a cohort of patients with Cushing's disease. J Clin Endocrinol Metab. 2004 Mar;89(3):1131-9.

22. Simmons NE, Alden TD, Thorner MO, Laws ER, Jr. Serum cortisol response to transsphenoidal surgery for Cushing disease. J Neurosurg. 2001 Jul;95(1):1-8.

23. Yap LB, Turner HE, Adams CB, Wass JA. Undetectable postoperative cortisol does not always predict long-term remission in Cushing's disease: a single centre audit. Clin Endocrinol (Oxf). 2002 Jan;56(1):25-31.

24. McCance DR, Besser M, Atkinson AB. Assessment of cure after transsphenoidal surgery for Cushing's disease. Clin Endocrinol (Oxf). 1996 Jan;44(1):1-6.

25. Trainer PJ, Lawrie HS, Verhelst J, et al. Transsphenoidal resection in Cushing's disease: undetectable serum cortisol as the definition of successful treatment. Clin Endocrinol (Oxf). 1993 Jan;38(1):73-8.

26. Burke CW, Adams CB, Esiri MM, Morris C, Bevan JS Transsphenoidal surgery for Cushing's disease: does what is removed determine the endocrine outcome? Clin Endocrinol (Oxf). 1990 Oct;33(4):525-37.

27. Blevins LS, Jr., Sanai N, Kunwar S, Devin JK. An approach to the management of patients with residual Cushing's disease. J Neurooncol. 2009 Sep;94(3):313-9.

28. Dickerman RD, Oldfield EH. Basis of persistent and recurrent Cushing disease: an analysis of findings at repeated pituitary surgery. J Neurosurg. 2002 Dec;97(6):1343-9.

29. De Tommasi C, Vance ML, Okonkwo DO, Diallo A, Laws ER, Jr. Surgical management of adrenocorticotropic hormone-secreting macroadenomas: outcome and challenges in patients with Cushing's disease or Nelson's syndrome. J Neurosurg. 2005 Nov; $103(5): 825-30$.

30. Meij B, Voorhout G, Rijnberk A. Progress in transsphenoidal hypophysectomy for treatment of pituitary-dependent hyperadrenocorticism in dogs and cats. Mol Cell Endocrinol 2002 Nov 29;197(1-2):89-96.

31. Swearingen B, Biller BM, Barker FG, 2nd, et al. Long-term mortality after transsphenoidal surgery for Cushing disease. Ann Intern Med. 1999 May 18;130(10):821-4.

32. Scheithauer BW, Gaffey TA, Lloyd RV, et al. Pathobiology of pituitary adenomas and carcinomas. Neurosurgery. 2006 Aug;59 (2):341-53; discussion 53.

33. Hague K, Post KD, Morgello S. Absence of peritumoral Crooke's change is associated with recurrence in surgically treated Cushing's disease. Surg Neurol. 2000 Jan;53(1):77-81.

34. Felix IA, Horvath E, Kovacs K. Massive Crooke's hyalinization in corticotroph cell adenomas of the human pituitary. A histological, immunocytological, and electron microscopic study of three cases. Acta Neurochir (Wien). 1981;58(3-4):235-43.

35. George DH, Scheithauer BW, Kovacs K, et al. Crooke's cell adenoma of the pituitary: an aggressive variant of corticotroph adenoma. Am J Surg Pathol. 2003 Oct;27(10):1330-6.

36. Nakane T, Kuwayama $A$, Watanabe $M$, et al. Long term results of transsphenoidal adenomectomy in patients with Cushing's disease. Neurosurgery. 1987 Aug;21(2):218-22.

37. Tindall GT, Herring CJ, Clark RV, Adams DA, Watts NB. Cushing's disease: results of transsphenoidal microsurgery with emphasis on surgical failures. J Neurosurg. 1990 Mar;72(3):363-9.

38. Pereira AM, van Aken MO, van Dulken $H$, et al. Long-term predictive value of postsurgical cortisol concentrations for cure and risk of recurrence in Cushing's disease. J Clin Endocrinol Metab. 2003 Dec;88(12):5858-64.

39. Knappe UJ, Ludecke DK. Persistent and recurrent hypercortisolism after transsphenoidal surgery for Cushing's disease. Acta Neurochir Suppl. 1996;65:31-4.

40. Hofmann BM, Hlavac M, Kreutzer J, Grabenbauer G, Fahlbusch R. Surgical treatment of recurrent Cushing's disease. Neurosurgery. 2006 Jun;58(6):1108-18; discussion 18. 
41. Tabarin A, Laurent F, Catargi B, et al. Comparative evaluation of conventional and dynamic magnetic resonance imaging of the pituitary gland for the diagnosis of Cushing's disease. Clin Endocrinol (Oxf). 1998 Sep;49(3):293-300.

42. Erickson D, Erickson B, Watson R, et al. 3 Tesla magnetic resonance imaging with and without corticotropin releasing hormone stimulation for the detection of microadenomas in Cushing's syndrome. Clin Endocrinol (Oxf). 2010 Jun;72(6): 793-9.

43. Kim LJ, Lekovic GP, White WL, Karis J. Preliminary Experience with 3-Tesla MRI and Cushing's disease. Skull Base. 2007 Jul; 17(4):273-7.

44. Oldfield EH, Doppman JL, Nieman LK, et al. Petrosal sinus sampling with and without corticotropin-releasing hormone for the differential diagnosis of Cushing's syndrome. N Engl J Med. 1991 Sep 26;325(13):897-905.

45. Locatelli M, Vance ML, Laws ER. Clinical review: the strategy of immediate reoperation for transsphenoidal surgery for Cushing's disease. J Clin Endocrinol Metab. 2005 Sep;90(9):5478-82.

46. Ram Z, Nieman LK, Cutler GB, Jr., Chrousos GP, Doppman JL, Oldfield EH. Early repeat surgery for persistent Cushing's disease. J Neurosurg. 1994 Jan;80(1):37-45.

47. Patil CG, Veeravagu A, Prevedello DM, Katznelson L, Vance ML, Laws ER, Jr. Outcomes after repeat transsphenoidal surgery for recurrent Cushing's disease. Neurosurgery. 2008 Aug;63(2):26670; discussion: 70-1.

48. Fatemi N, Dusick JR, de Paiva Neto MA, Kelly DF. The endonasal microscopic approach for pituitary adenomas and other parasellar tumors: a 10-year experience. Neurosurgery. 2008 Oct:63(4 Suppl 2):244-56; discussion 256

49. Dusick JR, Esposito F, Malkasian D, Kelly DF. Avoidance of carotid artery injuries in transsphenoidal surgery with the Doppler probe and micro-hook blades. Neurosurgery. 2007 Apr; 60(4 Suppl 2):322-8; discussion 328-9.

50. Jagannathan J, Smith R, DeVroom HL, et al. Outcome of using the histological pseudocapsule as a surgical capsule in Cushing disease. J Neurosurg. 2009 Sep;111(3):531-9.

51. Fatemi N, Dusick JR, Mattozo C, et al. Pituitary hormonal loss and recovery after transsphenoidal adenoma removal. Neurosurgery. 2008 Oct;63(4):709-18; discussion 718-9.

52. Cavallo LM, de Divitiis O, Aydin S, et al. Extended endoscopic endonasal transsphenoidal approach to the suprasellar area: anatomic considerations-part 1. Neurosurgery. 2007 Sep;61(3 Suppl):24-33; discussion 34 .

53. Kassam A, Snyderman CH, Mintz A, Gardner P, Carrau RL. Expanded endonasal approach: the rostrocaudal axis. Part I. Crista galli to the sella turcica. Neurosurg Focus, 2005 Jul 15;19 (1):E3.

54. Kassam A, Snyderman CH, Mintz A, Gardner P, Carrau RL. Expanded endonasal approach: the rostrocaudal axis. Part II Posterior clinoids to the foramen magnum. Neurosurg Focus. 2005 Jul 15;19(1):E4.

55. Kitano $M$, Taneda $M$, Shimono $T$, Nakao $Y$. Extended transsphenoidal approach for surgical management of pituitary adenomas invading the cavernous sinus. J Neurosurg. $2008 \mathrm{Jan}$; $108(1): 26-36$

56. Hardy J. Presidential address: XVII Canadian Congress of Neurological Sciences. Cushing's disease: 50 years later. Can J Neurol Sci. 1982 Nov;9(4):375-80.

57. Weil R.I, Vortmeyer AO, Nieman LK, Devroom HL, Wanebo J, Oldfield $\mathrm{EH}$. Surgical remission of pituitary adenomas confined to the neurohypophysis in Cushing's disease. J Clin Endocrinol Metab. 2006 Jul;91(7):2656-64.

58. Friedman RB, Oldfield EH, Nieman LK, et al. Repeat transsphenoidal surgery for Cushing's disease. J Neurosurg. 1989
Oct;71 (4):520-7.

59. Rudnik A, Zawadzki T, Galuszka-Ignasiak B, et al. Endoscopic transsphenoidal treatment in recurrent and residual pituitary adenomas-first experience. Minim Invasive Neurosurg. 2006
Feb;49(1):10-4.
60. Chee GH, Mathias DB, James RA, Kendall-Taylor P. Transsphenoidal pituitary surgery in Cushing's disease: can we predict outcome? Clin Endocrinol (Oxf). 2001 May;54(5): 617-26.

61. Benveniste RJ, King WA, Walsh J, Lee JS, Delman BN, Post KD. Repeated transsphenoidal surgery to treat recurrent or residual pituitary adenoma. J Neurosurg. $2005 \mathrm{Jun} ; 102(6)$ :1004-12.

62. Biller BM, Grossman AB, Stewart PM, et al. Treatment of adrenocorticotropin-dependent Cushing's syndrome: a consensus statement. J Clin Endocrinol Metab. 2008 Jul;93(7):2454-62.

63. Estrada J, Boronat $\mathrm{M}$, Mielgo $\mathrm{M}$, et al. The long-term outcome of pituitary irradiation after unsuccessful transsphenoidal surgery in Cushing's disease. N Engl J Med. 1997 Jan 16;336(3):172-7.

64. Becker G, Kocher M, Kortmann RD, et al. Radiation therapy in the multimodal treatment approach of pituitary adenoma. Strahlenther Onkol. 2002 Apr; 178(4):173-86.

65. Zierhut D, Flentje M, Adolph J, Erdmann J, Raue F, Wannenmacher M. External radiotherapy of pituitary adenomas. Int J Radiat Oncol Biol Phys. 1995 Sep 30;33(2):307-14.

66. Brada M, Ford D, Ashley S, et al. Risk of second brain tumour after conservative surgery and radiotherapy for pituitary adenoma. BMJ. 1992 May 23;304(6838):1343-6.

67. Simmons NE, Laws ER, Jr. Glioma occurrence after sellar irradiation: case report and review. Neurosurgery. 1998 Jan;42 (I): $172-8$.

68. Salinger DJ, Brady LW, Miyamoto CT. Radiation therapy in the treatment of pituitary adenomas. Am J Clin Oncol. 1992 Dec;15 (6):467-73.

69. Constine LS, Woolf PD, Cann D, et al. Hypothalamic-pituitary dysfunction after radiation for brain tumors. N Engl J Med. 1993 Jan 14;328(2):87-94

70. Colin P, Delemer B, Nakib I, et al. [Unsuccessful surgery of Cushing's disease. Role and efficacy of fractionated stereotactic radiotherapy]. Neurochirurgie. 2002 May:48(2-3 Pt 2):285-93.

71. Colin P, Jovenin N, Delemer B, et al. Treatment of pituitary adenomas by fractionated stereotactic radiotherapy: a prospective study of 110 patients. Int J Radiat Oncol Biol Phys. 2005 Jun 1;62(2):333-41.

72. Sheehan JP, Niranjan A, Sheehan JM, et al. Stereotactic radiosurgery for pituitary adenomas: an intermediate review of its safety, efficacy, and role in the neurosurgical treatment armamentarium. J Neurosurg. 2005 Apr; 102(4):678-91.

73. Sheehan JM, Vance ML, Sheehan JP, Ellegala DB, Laws ER, Jr. Radiosurgery for Cushing's disease after failed transsphenoidal surgery. J Neurosurg. 2000 Nov:93(5):738-42.

74. Jagannathan J, Sheehan JP, Pouratian N, Laws ER, Steiner L, Vance ML. Gamma Knife surgery for Cushing's disease. J Neurosurg. 2007 Jun; 106(6):980-7

75. Castinetti F, Nagai M, Dufour H, et al. Gamma knife radiosurgery is a successful adjunctive treatment in Cushing's disease. Eur J Endocrinol. 2007 Jan:156(1):91-8.

76. Oyesiku NM. Stereotactic radiosurgery for Cushing disease: a review, Neurosurg Focus. 2007;23(6):E14.

77. Kobayashi T, Kida Y, Mori Y. Gamma knife radiosurgery in the treatment of Cushing disease: long-term results. J Neurosurg. 2002 Dec:97 Suppl 5:422-8.

78. Petit JH, Biller BM, Yock TI, et al. Proton stereotactic radiotherapy for persistent adrenocorticotropin-producing adenomas. J Clin Endocrinol Metab. 2008 Feb;93(2):393-9.

79. Lyman JT, Phillips MH, Frankel KA, Levy RP, Fabrikant JI. Radiation physics for particle beam radiosurgery. Neurosurg Clin N Am. 1992 Jan;3(1):1-8.

80. Miller JW, Crapo L. The medical treatment of Cushing's syndrome. Endocr Rev. 1993 Aug: I4(4):443-58.

81. Fleseriu M, Loriaux DL, Ludlam WH. Second-line treatment for Cushing's disease when initial pituitary surgery is unsuccessful. Curr Opin Endocrinol Diabetes Obes. 2007 Aug;14(4):323-8.

82. O'Riordain DS, Farley DR, Young WF, Jr., Grant CS, van Heerden JA. Long-term outcome of bilateral adrenalectomy in patients with Cushing's syndrome. Surgery. 1994 Dec;116(6):1088-93; discussion 1093-4. 
83. Smith PW, Turza KC, Carter CO, Vance ML, Laws ER, Hanks JB. Bilateral adrenalectomy for refractory Cushing disease: a safe and definitive therapy. J Am Coll Surg. 2009 Jun;208(6): 1059-64.

84. Chow JT, Thompson GB, Grant CS, Farley DR, Richards ML, Young WF, Jr. Bilateral laparoscopic adrenalectomy for corticotrophin-dependent Cushing's syndrome: a review of the Mayo Clinic experience. Clin Endocrinol (Oxf). 2008 Apr;68 (4):513-9.

85. Thompson SK, Hayman AV, Ludlam WH, Deveney CW, Loriaux DL, Sheppard BC. Improved quality of life after bilateral laparoscopic adrenalectomy for Cushing's disease: a 10-year experience. Ann Surg. 2007 May;245(5):790-4

86. Assie G, Bahurel H, Coste J, et al. Corticotroph tumor progression after adrenalectomy in Cushing's Disease: a reappraisal of Nelson's Syndrome. J Clin Endocrinol Metab. 2007 Jan;92(1): 172-9.

87. Pereira MA, Halpern A, Salgado LR, et al. A study of patients with Nelson's syndrome. Clin Endocrinol (Oxf). 1998 Oct;49(4): 533-9.

88. Nagesser SK, van Seters AP, Kievit J, et al. Treatment of pituitarydependent Cushing's syndrome: long-term results of unilateral adrenalectomy followed by external pituitary irradiation compared to transsphenoidal pituitary surgery. Clin Endocrinol (Oxf). 2000 Apr;52(4):427-35.

89. Invitti C, Giraldi FP, de Martin M, Cavagnini F. Diagnosis and management of Cushing's syndrome: results of an Italian multicentre study. Study Group of the Italian Society of Endocrinology on the Pathophysiology of the HypothalamicPituitary-Adrenal Axis. J Clin Endocrinol Metab. 1999 Feb; 84(2):440-8

90. Favia G, Boscaro M, Lumachi F, D'Amico DF. Role of bilateral adrenalectomy in Cushing's disease. World J Surg. 1994 JulAug: 18(4):462-6.

91. Kemink SA, Wesseling P, Pieters GF, Verhofstad AA, Hermus AR, Smals AG. Progression of a Nelson's adenoma to pituitary carcinoma; a case report and review of the literature. J Endocrinol Invest. 1999 Jan;22(1):70-5.

92. Nagesser SK, van Seters AP, Kievit J, Hermans I, Krans HM, van de Velde CJ. Long-term results of total adrenalectomy for Cushing's disease. World J Surg. 2000 Jan;24(1):108-13.

93. Kemink SA, Grotenhuis JA, De Vries J, Pieters GF, Hermus AR, Smals AG. Management of Nelson's syndrome: observations in fifteen patients. Clin Endocrinol (Oxf). 2001 Jan;54(1):45-52.
94. Saeger W. Surgical pathology of the pituitary in Cushing's disease. Pathol Res Pract. 1991 Jun;187(5):613-6.

95. Kelly PA, Samandouras G, Grossman AB, Afshar F, Besser GM, Jenkins PJ. Neurosurgical treatment of Nelson's syndrome. J Clin Endocrinol Metab. 2002 Dec;87(12):5465-9.

96. Wislawski J, Kasperlik-Zaluska AA, Jeske W, et al. Results of netrosurgical treatment by a transsphenoidal approach in 10 patients with Nelson's syndrome. J Neurosurg. 1985 Jan;62(1): 68-71.

97. Xing B, Ren Z, Su C, Wang R, Yang Y, Hu Y. Microsurgical treatment of Nelson's syndrome. Chin Med J (Engl). 2002 Aug; $115(8): 1150-2$.

98. Ganz JC, Aanderud S, Mork SJ, Smievoll AI. Tumour volume reduction following gamma knife radiosurgery: the relationship between X-ray and histological findings. Acta Neurochir Suppl. 1994;62:39-42.

99. Jenkins PJ, Trainer PJ, Plowman PN, et al. The long-term outcome after adrenalectomy and prophylactic pituitary radiotherapy in adrenocorticotropin-dependent Cushing's syndrome. J Clin Endocrinol Metab. 1995 Jan;80(1):165-71.

100. de Bruin C, Feelders RA, Lamberts SW, Hofland LJ. Somatostatin and dopamine receptors as targets for medical treatment of Cushing's Syndrome. Rev Endocr Metab Disord. 2009 Jun;10 (2):91-102.

101. Batista DL, Zhang X, Gejman R, et al. The effects of SOM230 on cell proliferation and adrenocorticotropin secretion in human corticotroph pituitary adenomas. J Clin Endocrinol Metab. 2006 Nov;91(11):4482-8.

102. Hofland LJ, van der Hoek J, Feelders R, et al. The multi-ligand somatostatin analogue SOM230 inhibits ACTH secretion by cultured human corticotroph adenomas via somatostatin receptor type 5. Eur J Endocrinol. 2005 Apr; 152(4):645-54.

103. Moyes VJ, Alusi G, Sabin HI, et al. Treatment of Nelson's syndrome with temozolomide. Eur J Endocrinol. 2009 Jan; 160(1):115-9.

104. Ragel BT, Couldwell WT. Pituitary carcinoma: a review of the literature. Neurosurg Focus. 2004 Apr 15;16(4):E7.

105. Landman RE, Horwith M, Peterson RE, Khandji AG, Wardlaw SL. Long-term survival with ACTH-secreting carcinoma of the pituitary: a case report and review of the literature. J Clin Endocrinol Metab. 2002 Jul;87(7):3084-9. 